\title{
84. On the Blood Group Substances of Lactobacillus Bifidus
}

\author{
By Akira Amano \\ Department of Pediatrics and Legal Medicine, Tokyo Medical and Dental University \\ (Comm. by T. Furuhata, M.J.A., July 12, 1962)
}

It is well known that some kinds of bacteria have blood group substances. ${ }^{11}$ This report is concerned with the blood group substances of Lactobacillus bifidus.

Forty-two strains of Lactobacillus bifidus were isolated from faeces of infants in our department,, and they were divided into 5 groups according to Dehnert's classification. ${ }^{3)}$ One strain was selected from each group and was investigated for blood group substances. Being cultivated in Negishi's liquid medium ${ }^{4}$ for 48 hours, the bacillus was collected, washed, lyophilized and used for tests. The inhibition tests of anti-A and anti-B isohemagglutinins showed that the growth medium was not contaminated by the blood group substances.

Blood group A activity was neither demonstrated by immunization tests of rabbits of A salivary type ${ }^{5)}$ (anti-A type), ${ }^{6}$ nor by absorption tests of anti-A isohemagglutinin or sheep hemolysin with a bacillus of any group.

Blood group B activity was demonstrated in the Lactobacillus of every group by immunization tests. By immunizing chicken with it, agglutinin titers for human B cells were enhanced in the sera.

The results of cross absorption tests of the immune agglutinins for human B cells with the bacillus were as follows: immune anti-B agglutinins were easily removed by absorption with a homologous bacillus. Anti-B agglutinin produced by immunization with the bacillus of group I was scarcely absorbed with bacilli of other groups. Anti-B agglutinin produced in chicken sera with groups II, IV, and $\mathrm{V}$ was absorbed fairly well with groups IV and V, and that produced with group III was easily absorbed with groups I, II, and V, but not with group IV. These results suggest that there are some qualitative differences between the $\mathrm{B}$ antigens of each group.

The agglutinin for human B cells produced by immunization with the bacillus of groups I, II, IV, and V was completely removed by absorption with human $\mathrm{B}\left(\mathrm{B}_{\mathrm{I}} \mathrm{B}_{\mathrm{II}} \mathrm{B}_{\mathrm{III}}\right)$ or rabbit $\left(\mathrm{B}_{\mathrm{II}} \mathrm{B}_{\mathrm{III}}\right)$ cells and partially with guinea-pig cells $\left(\mathrm{B}_{\mathrm{III}}\right),{ }^{7}$, whereas that produced by immunization with group III was completely removed by absorption with human B, rabbit or guinea-pig cells. It is supposed from these data that blood group B substances in the Lactobacillus bifidus groups 
I, II, IV, and V consisted of $\mathrm{B}_{\mathrm{II}} \mathrm{B}_{\mathrm{III}}$, while group III consisted only of $\mathrm{B}_{\mathrm{IIT}}$.

Blood group B substance could not be demonstrated by absorption tests of normal human anti-B and immune anti- $\mathrm{B}_{\mathrm{I}}$, anti- $\mathrm{B}_{\mathrm{II}}$, and anti- $\mathrm{B}_{\text {III }}$ hemagglutinins.

Blood group $\mathrm{O}(\mathrm{H})$ substance was demonstrated by immunization tests with the Lactobacillus bifidus groups IV and V, but not with groups I, II, and III. By immunizing with groups IV and V, agglutinins in chicken for human $\mathrm{A}, \mathrm{B}$, and $\mathrm{O}$ cells were produced.

These were removed by absorption with Se human saliva, shigella flexneri $3 \mathrm{a}$, and a homologous bacillus, but not with se human saliva. The blood group $\mathrm{O}(\mathrm{H})$ substance was also removed by absorption with rat $\left(\mathrm{O}_{\mathrm{II}} \mathrm{O}_{\mathrm{III}}\right)$ or rabbit cells $\left(\mathrm{O}_{\mathrm{III}}\right){ }^{8)}$ so that the $\mathrm{O}(\mathrm{H})$ substances in groups IV and $\mathrm{V}$ were consisting of $\mathrm{O}_{\mathrm{III}}$.

Agglutinin for human $\mathrm{O}$ cells in eel serum was absorbed with the bacillus of group III but not with any other groups. Anti-O(H) agglutinin produced in chicken sera immunized with OSe human saliva was not absorbed with any group.

Blood group $\mathrm{C}$ substance, which is considered to be common in $\mathrm{A}$ and $\mathrm{B}$ cells, ${ }^{9)}$ could not be demonstrated in any group either by immunization tests of chicken or by absorption tests of anti-C agglutinin that produced in a chicken serum, which was immunized with Lactobacillus brevis. ${ }^{1)}$ Also Forssman antigen could not be demonstrated.

Kagayama ${ }^{10)}$ reported an antigen which was common in rabbit, guinea-pig, and rat cells but not demonstrated in human cells. Nunome ${ }^{11}$ named it "X-antigen". By immunization of chicken with the bacilli of groups II, III, IV, and V, hemagglutinins for rabbit, guinea-pig, and rat cells were produced, whereas by immunization with group I the hemagglutinin for cells of these animals was not produced. Cross absorption tests of these $\mathrm{X}$ agglutinins were carried out. Anti-X agglutinins for guinea-pig and rat cells of group II was absorbed by the bacillus of group I, but that for rabbit cells was not. Bacilli other than of group I absorbed completely the anti-X agglutinin of group II. Anti-X agglutinin of groups III and $\mathrm{V}$ was absorbed only by a homologous bacillus. Anti-X agglutinin of group IV was absorbed completely by a homologous bacillus, and that for rat cells was absorbed also by the bacillus of other groups, but that for guinea-pig and rabbit cells was not.

In order to determine that in what fraction of the bacilli these antigens exsisted, inhibition tests of anti-B, anti-O, and anti-X agglutinins produced by immunization with bacilli were carried out with carbohydrate-like, protein-like, and lipid-like fraction of homo- 
logous bacilli. Fractions from the bacillus were obtained according to Hayakawa's method. ${ }^{12}$ B, $\mathrm{O}$, and X antigens were demonstrated mainly in carbohydrate-like fraction of each group.

The blood group substances of Lactobacillus bifidus are summarized in the following table.

The blood group substances of Lactobacillus bifidus

\begin{tabular}{c|ccccc}
\hline \multirow{2}{*}{$\begin{array}{c}\text { Blood group } \\
\text { antigen }\end{array}$} & \multicolumn{5}{|c}{ Lactobacillus bifidus } \\
\cline { 2 - 6 } & Group I & Group II & Group III & Group IV & Group V \\
\hline $\mathrm{A}$ & - & - & - & - & - \\
$\mathrm{B}$ & $\mathrm{B}_{\mathrm{II}} \mathrm{B}_{\mathrm{III}}$ & $\mathrm{B}_{\mathrm{II}} \mathrm{B}_{\mathrm{III}}$ & $\mathrm{B}_{\mathrm{III}}$ & $\mathrm{B}_{\mathrm{II}} \mathrm{B}_{\mathrm{III}}$ & $\mathrm{B}_{\mathrm{II}} \mathrm{B}_{\mathrm{III}}$ \\
$\mathrm{C}$ & - & - & - & - & - \\
0 & - & - & - & $\mathrm{O}_{\mathrm{III}}$ & $\mathrm{O}_{\mathrm{III}}$ \\
Forssman & - & - & - & - & - \\
$\mathrm{X}$ & - & + & + & + & + \\
\hline
\end{tabular}

\section{References}

1) Ichimura, T.: Act. Crim. Japon., 27, 183 (1961).

2) Amano, A.: Act. Crim. Japon., 28, 1 (1962).

3) Dehnert, J.: Zbt. Bakt. Abt. I. Orig., 169, 66 (1957).

4) Negishi, A.: Excerpta med., Sect. IV, 12, 573 (1959).

5) Koshino, T.: Juzen Igk. Z., 43, 3385 (1938).

6) Pettenkofer, H. J., et al.: Z. ImmunForsch., 119, 415 (1960).

7) Friedenreich, V. et al.: Z. ImmunForsch., 78, 152 (1933).

8) Inoue, Y.: Tokyo J. Med. Sci., 57(2), suppl. 1 (1943).

9) Kobayashi, C.: Tokyo J. Med. Sci., 56(11), suppl. 381 (1942).

10) Kagayama, S.: Chiba Igk. Z., 13, 982 (1935).

11) Nunome, T.: Proc. Japan Acad., 25(10), 23 (1949).

12) Hayakawa, Y.: Ochanomizu M. J., 2, 155 (1954). 